\title{
Rocznice „rewolucji rosyjskiej” w propagandzie władz sowieckich w latach 1933-1939
}

\begin{abstract}
Abstrakt: Władze Związku Sowieckiego celebrowały rozmaite rocznice w celach propagandowych. Kolejne obchody rewolucji październikowej służyły reżimowi Józefa Stalina do prezentowania treści istotnych dla jego polityki wewnętrznej i zagranicznej. Artykuł przedstawia propagandę sowiecką z okazji rocznic rewolucji w latach 1933-1939.
\end{abstract}

Słowa kluczowe: Związek Sowiecki, rewolucja rosyjska, propaganda, rocznice rewolucji, Międzynarodówka Komunistyczna, polityka sowiecka w latach 1933-1939.

Abstract: The Soviet Union authorities celebrated various anniversaries for propaganda purposes. Successive celebrations of the "October Revolution" served Joseph Stalin's regime to present the content important for its internal and foreign policy. The article deals with Soviet propaganda on the occasion of the revolution successive anniversaries in 1933-1939.

Keyw ords: Soviet Union, Russian Revolution, propaganda, revolution's anniversary, Communist International, Soviet policy 1933-1939.

System sowiecki, jak każdy reżim totalitarny, uwielbiał świętować różnego rodzaju rocznice i wykorzystywać takie okazje do celów propagandowych. Akurat władze Związku Socjalistycznych Republik Sowieckich miały szczególne w tym kierunku skłonności, a w okresie wzmacniania się osobistej dyktatury Józefa Stalina nasilały się one dodatkowo. Z czasem wykształcił się wokół osoby „ojca narodów” „kult jednostki”, przypisujący właśnie jemu wszelkie możliwe zasługi ${ }^{1}$. Obchody Dnia Kobiet (8 marca), Święta Pracy

${ }^{1}$ G.B. Kulikowa, Iz istorii formirowanija kulta licznosti Stalina (A. Barbius i sozdanije biografii „otca narodow” w naczale 1930-ych gg.), „Otieczestwiennaja Istorija” 2006, № 1, s. 98-107. 
(1 maja), powstania Armii Czerwonej, rocznic wybuchu I wojny światowej począwszy od 1 VIII 1935 r. jako dnia apeli antywojennych, rocznic powstania I Międzynarodówki, dni leninowskich w rocznicę śmierci Włodzimierza I. Lenina w styczniu i wielu kolejnych komunistycznych „świąt" miały swoja oprawę i każdorazowo przygotowano na te okazje starannie dobrane treści ${ }^{2}$. Wśród nich rocznice przejęcia władzy w Rosji przez bolszewików posiadały szczególne znaczenie. Wszak bez wydarzeń w nocy z 7 na 8 XI 1917 r. nie powstałaby władza sowiecka, a w konsekwencji nie byłoby czego świętować. Obok obchodów pierwszomajowych kolejne rocznice „rewolucji rosyjskiej”, bo tak oficjalnie nazywano przewrót bolszewicki w okresie międzywojennym, należały do najstarszych obchodzonych uroczyście „świąt” w ZSRS.

Lata 1933-1939 w sowieckiej polityce zagranicznej to okres wyznawania zasad bezpieczeństwa zbiorowego. Począwszy od decyzji Komitetu Centralnego Wszechzwiązkowej Komunistycznej Partii (bolszewików) [WKP(b)] z 13 XII 1933 r., w której ogólnie zasygnalizowano zmianę kursu w proniemieckich dotąd krokach Moskwy na tory bezpieczeństwa zbiorowego, nastapiły kolejne deklaracje najważniejszych w państwie osób na przełomie 1933/1934 r. Za najważniejsze uznać należy wystapienia Wiaczesława Mołotowa i Maksima Litwinowa na Wszechrosyjskim Zjeździe Sowietów (kolejno 28 i 29 XII 1933 r.) oraz Stalina z 26 I 1934 r. na XIV Zjeździe partii. Istotne znaczenie miał również krótki wywiad, jakiego sowiecki przywódca udzielił Walterowi Duranty'emu, moskiewskiemu korespondentowi „New York Timesa” 25 XII 1933 r. W skrócie nową politykę ZSRS określić można by jako współpracę wszystkich „miłujących pokój” narodów przeciwko agresorom. Za najgroźniejszych na tym etapie uznawano „niemiecki faszyzm” i ,japoński militaryzm”. Koniecznością stawała się, według sowieckich przywódców, „walka o pokój”. Litwinow twierdził, iż należało go uznać za „niepodzielny”, gdyż każdy, najmniejszy nawet konflikt lokalny, groził wojną na skalę światową. Z kolei Stalin dopuszczał w tym względzie współpracę Moskwy z Ligą Narodów, której dobre intencje całkowicie do tej pory negowano, oskarżając organizację genewską o „przygotowania do imperialistycznej agresji” przeciwko ZSRS ${ }^{3}$.

Należy zauważyć jeszcze jedną istotna zmianę w dotychczasowych działaniach reżimu komunistycznego. Jak wiadomo, jednym z dwóch ramion, których używano do prowadzenia polityki zagranicznej Kremla, była, oprócz

\footnotetext{
${ }^{2}$ D. Jeziorny, Stosunki pomiędzy Moskwa a Komunistyczna Partia Wielkiej Brytanii (19341936) $w$ świetle dokumentów brytyjskiego wywiadu radiowego, w: $Z$ dziejów Rosji i Polski w XX wieku. Księga dedykowana profesorowi Richardowi Pipesowi, red. H. Kocój, R. Małek, M. Szczerbiński, Gorzów Wlkp. 2006, s. 100.

${ }^{3}$ Więcej zob. W. Materski, ZSRR wobec kwestii bezpieczeństwa zbiorowego w okresie międzywojennym (Liga Narodów, rozbrojenie, systemy regionalne), „Studia z Dziejów ZSRR i Europy Środkowej” 1980, t. XVI, s. 124-131; D. Jeziorny, Pakt Ribbentrop-Mołotow - przełom czy kontynuacja w europejskiej polityce Zwiazku Sowieckiego, „Polski Przegląd Stosunków Międzynarodowych” R. II, 2012, s. 151-183.
} 
Ludowego Komisariatu Spraw Zagranicznych (LKSZ), Międzynarodówka Komunistyczna, zwana III Międzynarodówką lub w skrócie Kominternem. W tzw. trzecim okresie, który rozpoczą się w 1928 r. od wypowiedzi Nikołaja Bucharina $^{4}$, hasłem przewodnim w enuncjacjach Międzynarodówki stał się „socjalfaszyzm”. Rozumiano pod nim uznanie partii socjaldemokratycznych oraz związanych z nimi związków zawodowych za tak dalece „wrośniętych” w ustrój „demokracji burżuazyjnej”, że „hamowały rewolucję proletariacka wbrew woli mas”, „demoralizujac je” i „odciagając od ich podstawowych interesów". Demokracja w myśl doktryny Eduarda Bernsteina w 1899 r. ${ }^{5}$ była zdecydowanie lepszą i skuteczniejszą drogą do poprawy bytu robotników, co podkreślano szczególnie mocno po pierwszych doświadczeniach władzy bolszewików w Rosji, nasyconych aktami terroru. Według interpretacji bolszewickiej socjaldemokratyczni liderzy stanowili więc ucieleśnienie wszelkiego zła w ruchu robotniczym, powodując rozłam w nim. Najistotniejszym celem tak agresywnych w swojej wymowie ataków była Socjaldemokratyczna Partia Niemiec (SPD) - najsilniejsza partia robotnicza Europy, nie licząc rządzącej w Związku Sowieckim WKP(b). W 1934 r., czyli już po rozbiciu SPD przez reżim Adolfa Hitlera, zaczęły w Kominternie dochodzić do głosu inne poglądy. Zaowocowały one ostatecznie przyjęciem przez VII Zjazd tej organizacji taktyki frontów ludowych, które należało tworzyć w państwach demokratycznych celem przeciwstawienia się faszyzmowi. Oznaczało to współdziałanie komunistów z socjalistami, socjaldemokratami i innymi chętnymi do takiej współpracy ugrupowaniami ${ }^{6}$.

Dlatego też $\mathrm{w}$ prezentowanym artykule istotne będzie przyjrzenie się, czy z powodu kolejnych rocznicowych obchodów rewolucji październikowej zauważalne były treści, które podkreślały wzmacnianie dyktatury Stalina w ZSRS, bezpieczeństwo zbiorowe w polityce zagranicznej kraju czy propagowanie taktyki Kominternu. Czy oprócz wskazanych tematów poruszano w trakcie okolicznościowych przemówień i manifestów jakieś inne wątki? Jakie

\footnotetext{
${ }^{4}$ Więcej o periodyzacji dziejów Kominternu zob. K. McDermott, J. Agnew, The Comintern. A History of International Communism from Lenin to Stalin, Basingstoke 1996, s. 97-120; K. McDermott, Stalin and the Comintern during the „Third Period”, 1928-1933, „European History Review” 1995, vol. XXV, no. 3, s. 409-429.

${ }^{5}$ Więcej o myśli Bernsteina zob. L. Kołakowski, Główne nurty marksizmu, cz. 2: Rozwój, Warszawa 1989, s. 439-449.

${ }^{6}$ Szerzej na temat podejścia Międzynarodówki Komunistycznej do kwestii współpracy z kierownictwem Socjalistycznej Międzynarodówki Robotniczej oraz pomiędzy sekcjami narodowymi Kominternu z partiami socjalistycznymi i socjaldemokratycznymi w poszczególnych państwach zob. G. Borsányi, The Life of the Communist Revolutionary, Béla Kun, New York 1993, s. 346-347, 369-371; F. Furet, Przeszłość pewnego złudzenia. Esej o idei komunistycznej $w X X w$., tłum. J. Górnicka-Kalinowska, M. Ochab, Warszawa 1996, s. 274-306, 346-356; S.A. McMeekin, Münzenberg. Rise and Fall of a Communist Tycoon, 1917-1940, Ph.D. University of California, Berkeley 2001, s. 437-439, http://proquest.umi. com (dostęp: 3 IV 2009).
} 
proporcje zajmowały zagadnienia wewnętrzne i zewnętrzne w wygłaszanych przy tej okazji enuncjacjach? Do kogo były one w głównej mierze adresowane i w jaki sposób to czyniono? Do czego w ogóle wykorzystywano obchody udanego przewrotu bolszewickiego z 1917 r.? Czy oprócz publikowania kolejnych dokumentów „ku czci” starano się sięgnąć po inne narzędzia wpływania na opinię publiczną? Na powyższe pytania badawcze można udzielić odpowiedzi, analizując wypowiedzi najważniejszych polityków w Związku Sowieckim lub wyznaczonych przez nich do tego osób.

Najważniejszym do przeanalizowania źródłem są w tym wypadku manifesty, które przy okazji kolejnych rocznic rewolucji rosyjskiej ogłaszał Komitet Wykonawczy Międzynarodówki Komunistycznej (KW MK). Jemu właśnie władze sowieckie powierzyły zadanie przygotowania odpowiedniego dokumentu na obchody „Wielkiego Października”. Mimo że oficjalnie Kreml i LKSZ dystansowały się wielokrotnie od jakiegokolwiek wpływu na Komintern, dzisiejsze ustalenia naukowe nie pozostawiają żadnych wątpliwości, iż posiadająca swą siedzibę w moskiewskim hotelu „Lux” organizacja była zależna w swoich decyzjach od kierownictwa RKP/WKP(b). Po roku 1929 można już mówić o całkowitym uzależnieniu, także w wymiarze personalnym. Zanim w KW MK podjęto jakiekolwiek kluczowe decyzje, dochodziło do spotkań z delegacją RKP(b), a w późniejszych latach WKP(b), która jako ciało nieujęte $\mathrm{w}$ żadnym paragrafie statutu Kominternu przynosiła konkretne projekty rozwiązań lub ustosunkowywała się do pomysłów władz Międzynarodówki Manifesty rocznicowe KW MK analizowane będą problemowo według schematu zaznaczonego powyżej: sprawa dyktatury Stalina, polityka międzynarodowa, problemy międzynarodowego ruchu robotniczego i inne kwestie.

Gdy chodzi o podkreślanie wyjątkowej roli „ojca narodów”, to pierwsze tego typu czołobitne odniesienia pojawiły się w manifestach na rocznicę rewolucji rosyjskiej dopiero w 1935 i 1936 r., choć na corocznych paradach na Placu Czerwonym jego portrety dominowały obok portretów Lenina ${ }^{8}$. Wspomnienie Stalina nastapiło przy okazji podkreślania triumfów sowieckich odnoszonych

\footnotetext{
7 Szczegóły zob. F.I. Firsow, Stalin i Komintiern, „Woprosy Istorii” 1989, № 9, s. 3-19; W. Fomitschow, Organisation und Entwicklung der Aktenführung im Apparat der Komintern. Zusammensetzung und Inhalt der Bestände von Personalakten (am Beispiel des Beständes für Deutschalnd), w: Biographisches Handbuch zur Geschichte der Kommunistischen Internationale, Hrsg. M. Buckmiller, K. Meschkat, Berlin 2007, s. 55-63, P. Huber, Das Führungskorps der Komintern. Ein soziobiographischer Querschnitt, w: Biographisches Handbuch..., s. 196-202; idem, The Moscow Headquarter of the Comintern: Departments, Leading Organs, Soviet Influence and Decision Making, w: Mechanism of Power in the Soviet Union, ed. N.E. Rosenfeldt, B. Jensen, E. Kulavig, London 2000, s. 71-100; idem, Structure of the Moscow Apparatus of the Comintern and Decision-Making, w: International Communism and the Communist International, ed. T. Rees, A. Thorpe, Manchester 1998, s. 41-64.

${ }^{8}$ Zob. np.: The National Archives, Londyn (dalej: TNA), Foreign Office (dalej: FO), 371/17252, N8410/113/38, lord Chilston (ambasador brytyjski w ZSRS) do Johna Simona (szef FO), Moskwa, 24 XI 1933.
} 
przez minione 18 lat. To właśnie dzięki partii bolszewickiej, jednoczącej pod swoim przewodnictwem „przytłaczajaccą większość społeczeństwa sowieckiego” i stojacej za swoimi przywódcami Leninem i Stalinem, było to w ogóle możliwe. Jak widać, następowało już wówczas zrównywanie roli obu tych osób w historii ZSRS, co dla zewnętrznych obserwatorów oznaczało posiadanie przez Stalina dyktatorskiej władzy. Ale przy okazji nie omieszkano uzasadnić pierwszego z procesów pokazowych, który odbył się latem 1936 r. ${ }^{9}$ i przyniósł poważne szkody wizerunkowe sowieckiemu reżimowi za granicą. Jednakże sukcesy Związku Sowieckiego możliwe były, według autorów manifestu, ponieważ partia „zawsze bezlitośnie zwalczała oportunizm” i „oczyściła się z kontrrewolucyjnego trockizmu”, któremu udowodniono, iż był „bezpośrednim agentem faszystowskiej burżuazji”. Tylko taka właśnie partia „wzmocniona żelazną wolą i jasnym zrozumieniem wielkich celów walki” mogła tak wiele osiagnąć. Przy tej okazji nawoływano robotników z wszystkich krajów, aby „wzięli sobie do serca te lekcje wielkiej socjalistycznej rewolucji”. Oznaczało to ni mniej, ni więcej zachętę do naśladowania wzorców bolszewickich na gruncie innych państw ${ }^{10}$.

O wiele więcej akcentów odnoszących się do „wielkiego Stalina”, „giganta rewolucyjnej myśli i czynu” i jego „światłego przywództwa”, które doprowadziło do „ostatecznego i nieodwołalnego zwycięstwa socjalizmu w Związku Sowieckim", pojawiło się już w manifeście na 20. rocznicę rewolucji. Oprócz tradycyjnych stwierdzeń, że rosyjscy robotnicy i chłopi „pod przewodnictwem partii Lenina i Stalina zrzucili władzę kapitalistów i posiadaczy ziemskich i wprowadzili dyktaturę proletariatu”, wystapiły ostrzejsze ataki na „wrogów ludu, którzy dążą do odbudowania kapitalizmu w ZSRS”, na „sabotażystów, szkodników, kułaków, szpiegów i zdrajców trockistowsko-bucharinowskich". Wykorzenienie „tego gangu zdrajców jest niezbędną częścią składową zwycięskiej walki przeciw faszyzmowi i na rzecz pokoju między narodami”, jak stwierdzono w zakończeniu jubileuszowego manifestu. Mimo jednakże wszelkich przeszkód jego autorzy podkreślali sukcesy „na froncie budowy socjalizmu" i transformacji zacofanego kraju rolniczego do poziomu państwa „w większości przemysłowego”. I to właśnie te osiąnnięcia sprawiały, że „miliony ludzi na całym globie zwracały się ku socjalizmowi” i wykazywały „gorliwy entuzjazm” do walki o powtórzenie osiagnięć rosyjskich ${ }^{11}$.

${ }^{9}$ Chodzi o proces grupy Grigorija Zinowjewa i Lwa Kamieniewa z sierpnia 1936 r. Więcej zob. A. Bullock, Hitler $i$ Stalin. Żywoty równolegte, t. I, Warszawa 1993, s. 486-490.

10 TNA, FO, 371/19459, N5989/56/38, „Trud” z 7 XI 1935, manifest KW MK na 18. rocznicę rewolucji rosyjskiej; The Communist International, 1919-1943, vol. III: 1929-1943, ed. J. Degras, London-New York-Toronto 1965, s. 393, manifest KW MK na 19. rocznice rewolucji rosyjskiej, listopad 1936; TNA, FO, 371/19458, N6033/54/38, Chilston do Samuela Hoare'a (szef brytyjskiej dyplomacji w okresie czerwiec-grudzień 1935), Moskwa, 15 XI 1935.

11 The Communist International..., s. 414, 417, manifest KW MK na 20. rocznice rewolucji rosyjskiej, listopad 1937. 
Zdecydowanie mniej osobistych akcentów wiernopoddańczych wobec Stalina było obecnych w manifeście KW MK na 21. rocznicę rewolucji. Niemniej jednak w roku ukazania się „Historii Wszechzwiązkowej Komunistycznej Partii (bolszewików). Krótkiego kursu”, gdzie rolę „wielkiego wodza całego postępowego świata" należycie doceniono, w dokumencie Kominternu skupiono się na zaletach wprowadzenia dyktatury proletariatu. To właśnie ten system rządów pozwolił na „utrzymanie i wzmocnienie niepodległości, powstrzymanie najazdu wrogów i zbudowanie socjalizmu". Nawiązano w tym kontekście do „wytępienia gangu szpiegów trockistowsko-bucharinowskich” oraz do tego, że „naród sowiecki uczy jak prowadzić walkę przeciw zdrajcom, kapitulantom i wrogom ludu". Jeszcze ostrzejsze stwierdzenia padły rok później. KW MK próbował wówczas polaryzować świat na dobry i zły, doklejając do tego złego wszystkich skazanych w procesach pokazowych „starych bolszewików”. Przypisywano im, że byli „zdrajcami kraju i wrogami ludu”, współdziałającymi z „niemieckimi i japońskimi prowokatorami wojennymi” - określenia te zdobywać zaczęły w 1937 r. coraz większa popularność i po II wojnie światowej stosowano je z powodzeniem $\mathrm{w}$ krajach podporzadkowanych Zwiazkowi Sowieckiemu. W szczególny sposób odnoszono te złowrogie określenia do „trockistowskich agentów faszyzmu”. Należy się spodziewać, że chciano ta drogą uzasadnić nie tylko procesy pokazowe, ale i rozprawę z Partia Robotnicza Zjednoczenia Marksistowskiego (POUM) w Katalonii. Manifest na rok 1937 kończono podniosłym stwierdzeniem, że po 20 latach dyktatury proletariatu ,świadomy swej siły kraj sowiecki postępuje na swej drodze, czyniąc stanowcze i spokojne kroki [...] Jego dłoń onieśmiela wrogów, a wola chce przyjść z pomoca przyjaciołom”. W kwestii przyjaźni „stalinowskie słowo jest nieodwracalne”, jak głosiła deklaracja KW MK, a „granice sowieckiego państwa sa nienaruszalne". Bezpieczeństwo gwarantowała bowiem Związkowi Sowieckiemu „nieustępliwa, najsilniejsza armia świata, Armia Czerwona socjalizmu"12.

Podsumowując kwestię poruszania rządów Stalina w ZSRS przy okazji rocznic przejęcia władzy przez bolszewików, przyznać trzeba, że aspekt ten nie był jakoś szczególnie eksploatowany. W porównaniu z czołobitnymi deklaracjami składanymi dyktatorowi przy innych okazjach, rocznice przewrotu bolszewickiego służyły do przypominania jego osoby jedynie w kontekście rozprawy z przeciwnikami politycznymi i procesów pokazowych. Oznaczało to, że najwyraźniej przekazy Kominternu przeznaczone były dla odbiorców zewnętrznych, spoza ZSRS. Żyjący w demokratycznych krajach, nie będąc członkami partii komunistycznych, nie rozumieli hołdów uwielbienia składanych „wielkiemu wodzowi”.

12 Ibidem, s. 414-415, 417, 428-429, manifesty KW MK na 20. i 21. rocznicę rewolucji rosyjskiej, listopad 1937 i 1938. 
Zwracanie się do osób żyjacych poza Związkiem Sowieckim jest jeszcze bardziej jasne, gdy analizuje się treści dotyczące polityki międzynarodowej, głoszone przy okazji rocznic rewolucji rosyjskiej. Manifest KW MK wydany w listopadzie 1933 r. stwierdzał jasno, że świat stał w „przededniu nowej wojny światowej”. 5 lat później powrócono do tej konstatacji na początku kominternowskiego manifestu. Stwierdzano wówczas, że „druga wojna imperialistyczna” już się de facto zaczęła. Powodem była postawa „burżuazji, która chce zachować swą władzę”, sięgając po „faszyzm i imperialistyczna masakrę”. Dokument z roku 1933 precyzował, iż „nowa imperialistyczna wojna światowa" miałaby charakter antysowiecki, a jej celem byłby nowy podział świata. Na Wschodzie do wywołania jej dążył „japoński imperializm”, a na Zachodzie - „niemiecki faszyzm”, nazwany też „największym podżegaczem wojennym w Europie”. Niemcy pod władzą Hitlera nazywane były „kontrrewolucyjnym najemnikiem”, który „oferuje swe usługi całemu imperialistycznemu światu”. Przy okazji dostało się również innym mocarstwom. „Imperializm brytyjski” uznany został za „głównego organizatora wojennej kontrrewolucji przeciwko Związkowi Sowieckiemu", wpychającego narody do „krwawej łaźni”. Z kolei „imperializm francuski” miał zbierać siły w obronie „bandyckiego pokoju wersalskiego”. Wyścig zbrojeń pomiędzy największymi mocarstwami prowadził natomiast do „szczególnie ostrych imperialistycznych przeciwieństw”, które mogły przeistoczyć się w realną wojnę. Komentatorzy podkreślali, że właściwie tylko Stany Zjednoczone nie naraziły się na propagandową napaść, co mogło być podyktowane wizyta Litwinowa za oceanem, która zaowocowała nawiązaniem stosunków dyplomatycznych pomiędzy USA a ZSRS 16 XI $1933 \mathrm{r}$.

$\mathrm{Na}$ tle panujaccego powszechnie chaosu i niepewności Związek Sowiecki prezentował się jak „niezwyciężona skała”, „najsilniejsze centrum pokoju”, „obrońca narodów uciskanych i ludów kolonialnych” oraz „inspiracja robotników całego świata". Przez minione lata był on wielokrotnie prowokowany do wojny i gdyby nie „stał twardo przy sprawie pokoju, nowa wojna imperialistyczna wybuchłaby już dawno". Takie stwierdzenia musiały prowadzić do wniosku, że w razie jakiegokolwiek międzynarodowego konfliktu Moskwa nie zamierzała się w niego angażować. Za to bez wątpienia zdecydowanie „demaskowała plany imperialistów i wiele razy uniemożliwiała je”. Mówiąc bardziej współczesnym językiem, celem władz sowieckich mogło być propagandowe nagłaśnianie sporów w świecie kapitalistycznym, podsycanie ich i stanie z boku w razie wybuchu rzeczywistej wojny. Szczególnie piętnowano hitlerowskie Niemcy i Japonię, które oskarżano o jak najgorsze intencje, co zreszta w przypadku obu tych krajów w latach trzydziestych XX w. nie było dalekie od prawdy. Ze swej strony władcy ZSRS odgrażali się, że w razie ataku „awanturników” cel sformułowaliby jeden: „całkowite zniszczenie wroga i zwycięstwo naszej Armii Czerwonej”. Podkreślano więc, że Moskwa działała jedynie w obronie własnej, a ewentualne wkroczenie zbrojne na teren „wroga” to wyłącznie 
działanie na rzecz pokoju i wypełnienie złożonej uroczyście obietnicy ${ }^{13}$. Tyle że uzasadnienie rozpoczęcia walk to już sprawa propagandy.

W latach 1935-1936 nową inspiracją do atakowania ideologicznych wrogów stały się wojny w Abisynii i Hiszpanii. Dały one asumpt do twierdzeń, że „rośnie bezczelność” „niemieckiego faszyzmu” i „japońskiego imperializmu”, a także wychwalania „niezwyciężonej Armii Czerwonej”, która była „wiernym obrońcą sowieckiego państwa i prawdziwą tarczą pokoju narodów”. Przy tworzeniu jej potęgi oraz potencjału ekonomicznego chodziło wyłącznie o to, aby nikomu nie przyszło kiedykolwiek do głowy zaatakowanie ZSRS - tak interpretował zbrojenia sowieckie Litwinow na forum Centralnego Komitetu Wykonawczego Sowietów. W opinii twórców rocznicowego manifestu KW MK jasne było, iż Związek Sowiecki to „najpotężniejszy bastion przeciw wojnie i faszyzmowi”. Odróżniał się on w swej polityce zdecydowanie od hipokryzji w formie „polityki nieinterwencji”, która de facto służyła „interwencji faszystowskiej”. Zdaniem Litwinowa z kolei działania Moskwy pozostawały zawsze pokojowe, co przejawiało się w postulatach całkowitego i powszechnego rozbrojenia, zawierania paktów o nieagresji z sasiadami oraz regionalnych paktów zbiorowych do walki z agresorami. Wszystko to celem „wzmocnienia międzynarodowej solidarności na bazie paktu Ligi Narodów”, której zasady zawierały, w opinii Litwinowa, jego ulubioną koncepcje „niepodzielnego pokoju”. Nadzieje na porozumienie się z głównymi zwolennikami agresji Moskwa piętnowała. Ignorowanie gwałcenia traktatów międzynarodowych i „bezdyskusyjnej agresji”, czyli próby „usatysfakcjonowania” napadających zdobyczami w nadziei, iż „nie będą więcej grzeszyć”, bezwzględnie krytykowano. Litwinow słusznie przewidywał, jak bardzo nienasycone były ekspansywne zamiary Niemiec, Włoch czy Japonii. Każdy sukces i koncesję wykorzystywano do kolejnych agresji, stąd postulował „utworzenie silnego frontu” na rzecz narzucenia „faszystowskim agresorom przestrzegania granic i zachowania pokoju” oraz uniemożliwienia ich „kryminalnych planów”. Szef dyplomacji sowieckiej drwił również z lęku przed wspólnymi wystappieniami wobec napastników, aby nie narazić się na zarzut „tworzenia bloków”. Agresorzy, w jego opinii, nie wahali się tworzyć bloków polityczno-wojskowych. Obie uwagi Litwinowa co do nieskuteczności ustępstw oraz niechęci prowokowania agresorów były niewątpliwie słuszne i odnosiły się przede wszystkim do brytyjskiego appeasementu. Lecz alternatywę stanowiła przecież wojna i co do tego Moskwa na pewno nie mogła mieć wątpliwości. Oficjalnie jednak Litwinow tego nie stwierdził

${ }^{13}$ Dwa powyższe akapity na podstawie: ibidem, s. 276-278, 428-429, manifesty KW MK na 16. i 21. rocznicę rewolucji rosyjskiej, listopad 1933 i 1938 (pierwszy dostępny też w „International Press Correspondence” 1933, vol. XIII, no. 49, s. 1002-1003); Soviet Documents on Foreign Policy, vol. III: 1933-1941, ed. J. Degras, New York 1978, s. 34-35, przemówienie Mołotowa z 6 XI 1933; „Izwiestia” z 7 XI 1935, wstępniak na okazję rocznicy rewolucji; TNA, FO, 371/17252, N8411/113/38, Chilston do Simona, Moskwa, 16 XI 1933. 
i utrzymywał, iż proponowana przez ZSRS polityka bezpieczeństwa zbiorowego zapewniłaby pokój. Przyznawał się do chęci uczynienia państw europejskich bezkompromisowymi wobec krajów napadających. Natomiast manifest KW MK na rok 1938 nawoływał do prowadzenia „spójnej polityki”, której cecha charakterystyczna byłoby niewzbranianie się przed „zastosowaniem sankcji przeciw agresorom". Alternatywna droga uznana została przez Litwinowa jako „zaplanowana przez agresorów i ich agentów”. Szczególnie kraje małe i średnie były, w jego przekonaniu, podatne na uleganie agresorom. Szef dyplomacji sowieckiej nie wymienił ich, ale można było się domyślić, że za potencjalnych wrogów uznawał m.in. bezpośrednich zachodnich sasiadów ZSRS. Ironicznie porównał je nawet do krabów, które zbliżaja się do rekina w nadziei, iż nie połknie ich $\mathrm{w}$ całości ${ }^{14}$. Nie był to więc zupełnie ton, który mógł przekonać do współpracy z Moskwą mocarstwa zachodnie ani też uspokoić mniejszych sasiadów, np. Polskę, Rumunię czy państwa bałtyckie.

Na kanwie rozgrywającej się od 1936 r. wojny domowej w Hiszpanii, a od lipca następnego roku najazdu Japończyków na Chiny starano się najmocniej mobilizować rządy zachodnie do zajęcia jednoznacznego stanowiska. W jubileuszowych manifestach na kolejne rocznice bolszewickiego przewrotu październikowego podkreślano, że „lud hiszpański walczy w heroicznej walce [...] nie tylko przeciwko rebeliantom faszystowskim, ale też przeciw koalicji państw faszystowskich". W podobnej roli ustawiano Chińczyków zaangażowanych w „odważną obronę swego kraju” przed „japońskimi faszystowskimi militarystami”. Jednakże ataki na „niemiecki faszyzm” czy „japoński militarystyczny imperializm" nie były niczym nowym w wydaniu sowieckim. Obdarzanie ich najbardziej wymyślnymi określeniami, w stylu „podżegacze wojenni”, „rzezimieszki”, „bandyci” itp., różniło się już jedynie natężeniem siły epitetów. Bardziej znaczące były oskarżenia mocarstw, które na to nie reagowały. Ich rządy nazywano „hipokrytami i uzurpatorami”, czyli nie oszczędzano im krytyki. Coraz jaśniej płynęły z Moskwy żądania, aby domagać się, by rządy „państw burżuazyjno-demokratycznych” prowadziły walkę przeciwko „faszystowskim agresorom”, a także wywierać w tym kierunku „konieczna presję”. Dążenie do sprowokowania wojny w Europie Zachodniej przy zachowaniu neutralności ZSRS stawało się więc coraz mniej zawoalowane ${ }^{15}$.

Jednakże czary goryczy dopełniły wydarzenia roku 1938. Rocznica rewolucji rosyjskiej przypadała niedługo po konferencji monachijskiej z 29-30 września, która doprowadziła do uzgodnień mocarstw w kwestii Niemców Sudeckich na korzyść Niemiec. Co istotne, to nie „faszyzm niemiecki” był najsilniej

${ }^{14}$ The Communist International..., s. 394-395, 431-432, manifesty KW MK na 19. i 21. rocznice rewolucji rosyjskiej, listopad 1936; Soviet Documents on Foreign Policy..., s. 215-216, przemówienie Litwinowa z 10 XI 1936.

15 The Communist International..., s. 416-417, 431-432, manifesty KW MK na 20. i 21. rocznicę rewolucji rosyjskiej, listopad 1937 i 1938. 
atakowany tym razem w enuncjacjach płynaccych z Moskwy, lecz polityka państw zachodnich, zdeterminowana, według Dymitrowa, przez „reakcyjne kręgi imperialistyczne”, zwane też „klikami reakcjonistów angielskich i francuskich”. Kierował nimi lęk przed „rewolucją w Europie” i „wyswobodzeniem Azji”, a szczególnie „nienawiść do ZSRS”. Interesy własnych narodów „poświęcili faszyzmowi”, z którym zawarli „kontrrewolucyjny sojusz”. Przywódca Kominternu stwierdzał, że rządy w Londynie i Paryżu wiedziały, jak łatwe było zmuszenie Hitlera do wycofania się, ale nie chciały „wstrząsnać fundamentami faszyzmu”. Wybrali więc „obronę interesów klasowych” kosztem narodów mniejszych oraz narodu francuskiego, „wokół którego szyi faszyzm niemiecki i włoski zaciskają coraz mocniej pętlę". Aby zrealizować swój plan, dopuścili się „tajnego, wcześniej ukartowanego skandalicznego spisku”. Ten motyw kilkukrotnie powtarzany był w rocznicowym manifeście KW MK. „Spiskowcy z Monachium”, zwani też „kapitulantami”, weszli w rolę „obrońców pokoju", ale uratowali jedynie nieprzygotowanego do wojny Hitlera, głosząc hasło „pokoju za wszelką cenę”. W myśl kominternowskiej deklaracji w czasie kryzysu czechosłowackiego godny zaufania pozostawał więc jedynie Zwiąek Sowiecki ze swoją „niezachwianą lojalnością” co do podjętych zobowiązan, choć badania postsowieckich materiałów archiwalnych wskazywały raczej, że Armia Czerwona nie była gotowa pójść na pomoc Pradze. Jeśli już miałaby przeciw komuś występować, to jedynie „przeciwko faszystowskiej Polsce”, aby „wziąć Warszawę” i „zetrzeć z powierzchni ziemi faszystowskich gadów”. Takimi hasłami karmiono, według Michaiła Mieltiuchowa, czerwonoarmistów w celu podniesienia ich morale ${ }^{16}$.

Zupełnie inne treści dominowały natomiast w czasie obchodów 22. rocznicy rewolucji rosyjskiej. Przypomnieć należy, że pojawiały się one już w czasie wojny, która rzeczywiście wybuchła. Związek Sowiecki podpisał z hitlerowskimi Niemcami układ o nieagresji, do którego dołączono tajny protokół o podziale wpływów między oboma państwami na terenie Europy Środkowo-Wschodniej. Co więcej, Moskwa zaczęła już z dobrodziejstw tego dokumentu korzystać, podporzadkowujac sobie połowę Polski i wprowadzając wojska na ziemie państw bałtyckich. Tym razem więc rocznicowy manifest KW MK zawierał nowe akcenty. O samym Hitlerze stwierdzono jedynie, iż podpisanie układu z ZSRS to „przejaw słabości” z jego strony. Uznając potęgę „wielkiej socjalistycznej republiki”, musiał zgodzić się na traktat gwarantujący jej pokój. Innych krytycznych słów adresowanych do przywódcy III Rzeszy próżno szukać w manifeście. Dostało się za to „podżegaczom wojennym w Europie”,

${ }^{16}$ Ibidem, s. 427-432, wystapienie Dymitrowa z okazji 21. rocznicy „rewolucji rosyjskiej”, artykuł Dymitrowa dla „Communist International” 1938, nr 12 oraz manifest KW MK na 21. rocznice „rewolucji rosyjskiej”, listopad 1938; Z. Steiner, The Soviet Commissariat of Foreign Affairs and the Czechoslovakian Crisis in 1938: New Material from Soviet Archives, „The Historical Journal” 1999, vol. XLII, no. 3, s. 751-779; M. Mieltiuchow, Sowietsko-polskije wojny, izd. 2, Moskwa 2004, s. 274-280. 
którzy musieli wycofać się ze swoich planów „wplątania w wojnę" Związku Sowieckiego. Pakt sowiecko-niemiecki zwyczajnie wstrzasną „ich blokiem”. Działaczom Kominternu chodziło bez wątpienia o Wielką Brytanię i Francję, których działania były najbardziej krytycznie ocenione. Chodziło rzecz jasna o ich rządy, a nie o „proletariat, lud pracujaccy oraz pracujące chłopstwo”. Komuniści w Izbie Deputowanych zagłosowali za kredytami wojennymi dla rządu i propagandowo mobilizowali do stawienia czoła Niemcom w razie ich napaści na Francję i bronienia „wolności, narodowej niepodległości, zasad demokratycznych i cywilizacji”" 17 .

Podsumowując treści dotyczące polityki międzynarodowej, pojawiające się w wystapieniach najważniejszych polityków ZSRS i Kominternu, zauważyć należy, że zgodnie z wytycznymi polityki zagranicznej Kremla najwięcej krytyki dostało się Niemcom, a w następnej kolejności Japonii. Innym państwom poświęcono o wiele mniej miejsca, co odróżniało enuncjacje pojawiające się po roku 1933 od wcześniejszych, gdy dominowały akcenty antyfrancuskie i w drugiej kolejności antybrytyjskie. Obecnie Londynowi nadal przypisywano zamiary „zorganizowania” wojny przeciwko Związkowi Sowieckiemu, ale treści tego typu były o wiele rzadsze. Jeśli demokracje zachodnie spotykała ze strony Moskwy krytyka przy okazji obchodów, to przede wszystkim dlatego, że nie wystapiły otwarcie przeciwko kolejnym krokom Niemiec, Japonii czy Włoch w latach trzydziestych, gwałcacym porządek wersalski. ZSRS nie był co prawda jego zwolennikiem, ale na podstawie jego rocznicowych enuncjacji chciał doprowadzić Londyn i Paryż do wystapienia przeciwko agresorom, co musiało owocować wojna. Dodać należy, iż sam się od działań zbrojnych, przynajmniej w pierwszej ich fazie, dystansował. Można więc wysnuć wniosek, iż czekał na „wykrwawienie się” innym krajów.

Podobne wnioski nasuwają się, gdy czyta się fragmenty manifestów odnoszace się do kwestii jedności ruchu robotniczego. Były one obecne we wszystkich dokumentach wydawanych przez KW MK z okazji rewolucji październikowej (najsłabiej widoczne w manifeście z $1938 \mathrm{r} .{ }^{18}$ ). W listopadzie roku 1933 socjaldemokratów, bo tak nazywano adwersarzy komunistów w ramach ruchu robotniczego i nigdy nie pojawiło się słowo „socjaliści”, zwano wprost „kłamcami”, skoro proponowali „bezkrwawa drogę do socjalizmu”. Demokracja była przez Komintern napiętnowana jako system polityczny, ponieważ w jej imię socjaldemokraci wsparli burżuazyjna reakcję „krwią i żelazem” przeciwko „rewolucyjnej walce robotników o dyktaturę proletariatu”. Przypominano w tym kontekście wydarzenia toczące się tuż po I wojnie światowej

${ }^{17}$ The Communist International..., s. 439-442, manifest KW MK na 22. rocznicę rewolucji rosyjskiej, listopad 1939.

${ }^{18}$ Ibidem, s. 432-433, manifest KW MK na 21. rocznicę „rewolucji rosyjskiej”, listopad 1938. Stwierdzenia ograniczały się do rytualnego powtarzania, iż „miliony robotników na całym świecie żądają jedności” w szeregach klasy robotniczej, w tym wiele organizacji socjaldemokratycznych i związkowych. 
w Niemczech, Włoszech, Polsce, Austrii, Węgrzech i Finlandii. W związku z działalnościa socjaldemokratów „rewolucyjni robotnicy” osłabli w swej gorliwości, co w konsekwencji otwarło drogę dla faszystów. Przez to „setki tysięcy robotników i chłopów zostało poddanych egzekucjom faszystowskiej gilotyny”. W przeciwieństwie do Związku Sowieckiego sytuacja „dziesiątków milionów" bezrobotnych czy bezdomnych robotników, szczególnie młodych, okradanych z zarobków przez „wielką burżuazję”, „właścicieli ziemskich”, „pożyczkodawców, bankierów i poborców podatkowych” „w najbardziej cyniczny sposób” celem wyjścia z kryzysu, była godna pożałowania. Co gorsza, nie widziano końca kryzysu gospodarczego i niczemu nie pomogły „rabowanie budżetów narodowych”, „kontrakty zbrojeniowe”, powodowanie inflacji czy doprowadzanie do bankructwa „milionów małych i średnich farm”. Powyższe kroki prowadzić mogły, zdaniem autorów manifestu, do „coraz silniejszych sprzeczności w ramach systemu kapitalistycznego”. Na ekonomiczno-społecznych jego słabościach w czasie kryzysu, porównywanych z sukcesami sowieckimi, skupił się również w mowie z 7 XI 1933 r. przewodniczący Rady Komisarzy Ludowych, Mołotow. Jego przemówienie było zdecydowanie mniej barwne w porównaniu z manifestem Kominternu. Nie brakło w nim jednakże sformułowań o „zwierzęcym lęku” socjaldemokratów i „sił reakcji” przed komunizmem ${ }^{19}$.

Treści związane z rywalizacją z socjaldemokracją przeplatały się z uwagami na temat „faszyzmu”, choć w manifeście ani razu nie padło sformułowanie „socjalfaszyzm”, do niedawna najpopularniejsze we frazeologii komunistów. W listopadzie 1933 r. kojarzono faszyzm z Niemcami, celowo nie nazywając ich nazistami. To słowo zresztą w propagandzie sowieckiej pojawiało się niezwykle rzadko. W manifeście KW MK zaznaczono, iż najlepszą odpowiedzią „robotników całego świata”, daną „kryminalnej” socjaldemokracji działającej na rzecz rozłamu w szeregach robotniczych i faszyzmowi, byłaby „rewolucyjna obrona Związku Sowieckiego” wobec rosnącego naporu „imperialistów”. Nie wyjaśniono w dokumencie, jak miałaby taka walka wyglądać. Natomiast pochwalono „heroiczny opór” proletariatu niemieckiego. Komunizm, według KW MK, miał non stop wzrastać w siłę w Niemczech, a Komunistyczna Partia Niemiec (KPD) została uznana za jedyną siłe mogaca „poprowadzić rewolucyjny jednolity front przeciw faszyzmowi”. Było to trochę zaklinanie rzeczywistości, ponieważ większość aktywistów KPD siedziała wówczas w Dachau. Być może dlatego w końcówce manifestu zauważono, iż „tylko wsparcie całego światowego proletariatu mogłoby uwolnić niemiecki proletariat od władania faszyzmu i poprowadzić go na drogę Października”. Stąd pojawił się apel o zjednoczenie klasy robotniczej, które mogło nastapić ,jedynie ponad głowami przywódców socjaldemokracji, pod sztandarami rewolucji

${ }^{19}$ Ibidem, s. 277-278, manifest KW MK na 16. rocznicę rewolucji rosyjskiej, listopad 1933; TNA, FO, 371/17252, N8412/113/38, Chilston do Simona, Moskwa, 16 XI 1933. 
przeciw kapitalizmowi, faszyzmowi i reakcji”. W końcowym zdaniach manifestu Kominternu widać więc nie tylko tradycyjne dążenie do przeciągnięcia szeregowych członków partii i innych organizacji socjaldemokratycznych we własne szeregi. Choć sformułowanie o tworzeniu ,jednolitego frontu od dołu”, popularne od lat dwudziestych w propagandzie komunistów, nie pojawiło się $\mathrm{w}$ dokumencie, to w manifeście rocznicowym wyrażono cel realizacji tego programu wprost. Co więcej jednakże, wyraźna była zachęta wystosowana do Niemców, aby obalili reżim hitlerowski, w czym pomóc mieli sojusznicy z innych krajów ${ }^{20}$. Trudno więc oprzeć się wrażeniu, że chodziło o zawoalowane zaproszenie do interwencji antyniemieckiej krajów ościennych. Natomiast o wiele słabszy niż w poprzednich latach był nacisk władz Kominternu na promowanie ,światowej rewolucji”.

W kolejnych latach jednakże akcenty propagandy sowieckiej wobec Socjalistycznej Międzynarodówki Robotniczej oraz poszczególnych partii socjaldemokratycznych uległy przesunięciu. Od czerwca 1934 r. zarzucono stwierdzenia o „zdradzie socjaldemokratów” oraz o „socjalfaszyzmie”, a pomiędzy Francuska Partia Komunistyczna (FPK) a socjalistyczna Francuską Sekcja Międzynarodówki Robotniczej (SFIO) nawiązała się nić współpracy. Były to kroki całkowicie przeciwne dotychczasowym wytycznym Moskwy, ale budziły ogromny entuzjazm zwykłych robotników i szeregowych działaczy. Niechęć do nawiąywania porozumień zaczęto nazywać nastawieniem „sekciarskim” i piętnowaćéc. Już jednakże w lipcu 1934 r. Osip Piatnicki, odgrywający w Kominternie poważna, aczkolwiek nieoficjalną rolę, precyzował, że nie chodziło w tym zbliżeniu o jedność ideologiczna, lecz o wspólne działanie przeciwko faszyzmowi. Co do wyznawanych wartości należało „zniszczyć wszystkie iluzje robotników socjaldemokratycznych” i „zbliżyć masy do rewolucji proletariackiej”. De facto więc strategia komunistów pozostawała niezmienna - chodziło o pozyskanie aktywistów robotniczych w krajach zachodnich, udając współpracę i tym samym mając do tych ludzi dostęp ${ }^{22}$.

W manifestach na 17., 18. i 19. rocznice rewolucji rosyjskiej postawa taka znalazła odzwierciedlenie w całej pełni. Wzywano „masy robotnicze” do przeciwstawienia się faszyzmowi i wojnie. Ale skuteczne działanie wymagało jedności „pod przewodnictwem proletariatu” lub - jak pisano w innym miejscu - „pod czerwonym sztandarem Marksa, Engelsa, Lenina i Stalina”, czyli „pod sztandarem Międzynarodówki Komunistycznej”. Potrzebne było wspólne

20 The Communist International..., s. 278-279, manifest KW MK na 16. rocznice rewolucji rosyjskiej, listopad 1933.

${ }^{21}$ Cały proces nawiązywania porozumienia opisuje szczegółowo F. Kalicka, Problemy jednolitego frontu $w$ międzynarodowym ruchu robotniczym (1933-1935), Warszawa 1962. Autorka była ewidentną zwolenniczką porozumienia obu nurtów ruchu robotniczego, ale oceniała wszystko z pozycji jednoznacznie komunistycznych. Zob. też perspektywę brytyjska: K. Morgan, Harry Pollitt, Manchester 1993, s. 82-96.

${ }^{22}$ The Communist International..., s. 334-335. 
działanie, skoro ideologia dzieliła. Manifesty optymistycznie zapowiadały, że „robotnicy socjaldemokratyczni zrywają z reformizmem i kompromisem z burżuazja”. Jak więc widać, Kominternowi chodziło nie o coś innego niż o rewolucję, choć pod innymi niż w latach dwudziestych hasłami. Znakomita ilustracją tego procesu miały być powstanie robotnicze w Wiedniu i strajk generalny w obliczu wystapień nacjonalistycznej prawicy we Francji w lutym 1934 r., a także zryw robotników w Hiszpanii w październiku tego roku. Moskwa wielokrotnie próbowała je propagandowo wykorzystać, także przy okazji obchodów rewolucji. Uznawano wprawdzie porażki robotników, ale winni byli socjaldemokraci, którzy „rozbroili ich politycznie, nie prowadząc do walki z kapitalizmem”. Klasa rządząca zdecydowała się bowiem na wysłanie artylerii i lotnictwa przeciw walczącym robotnikom, „grzebiąc żywcem górników”. Każda kolejna godzina „kosztowała życie tysiące heroicznie walczących robotników i chłopów Hiszpanii wraz z ich żonami i dziećmi”. Stąd głoszono postulat porzucenia „demokratycznych iluzji” i okazania solidarności walczącym. Był to niewątpliwie apel do zwolenników socjaldemokracji celem rozsadzenia ich organizacji od wewnątrz, co w latach 1934-1935 miało niemałe szanse powodzenia po upadku SPD w Niemczech ${ }^{23}$.

Frazeologia manifestów Kominternu zmieniała się jednakże w tym aspekcie znacząco. W 1936 r. na kanwie wydarzeń w Hiszpanii pisano, że „jednolity front ludzi pracy i sił demokratycznych [...] jest w stanie zamknać drogę faszyzmowi”. Jeden z postulatów stanowiło zwołanie konferencji wszelkich organizacji robotniczych i utrzymywania z nimi stałego kontaktu. Jako że nie uzyskano akceptacji Socjalistycznej Międzynarodówki Robotniczej wobec tej niejasnej propozycji, to ponowiono wobec niej kolejne fale krytyki. Powtarzano słowa Stalina o konieczności wyeliminowania „dominujących wpływów socjaldemokracji”. Domagano się, aby nie pozwolić „reakcyjnym przywódcom socjaldemokracji” na „dalsze sabotowanie jednolitej akcji międzynarodowego ruchu robotniczego w obronie ludu Hiszpanii i Chin”. Tenże właśnie „faszyzm burżuazyjny” oskarżano o to, że w świecie kapitalistycznym „zwiększył ofensywę przeciw masom, ich organizacjom i instytucjom demokratycznym". O demokracji więc po raz pierwszy zaczęto pisać pozytywnie. Ale na pewno w Związku Sowieckim nie utożsamiano ich z demokratycznymi państwami Zachodu. „Siły imperializmu w Anglii” wspierały bowiem „niemiecki faszyzm” walczący po stronie gen. Francisca Franco, który był "tchórzliwie tolerowany” przez francuskich „demokratów”. Słowo „demokratów” napisano właśnie w cudzysłowie, aby dać wyraz dezaprobaty demokracji w wykonaniu Francuzów. Od prawdziwych „demokratycznej inteligencji” oraz „wszystkich sił demokratycznych na świecie” Moskwa oczekiwała „aktywnego wsparcia ludu hiszpańskiego” we współdziałaniu ze „wszystkimi siłami klasy robotniczej i chłopstwa pracującego". Z dużym entuzjazmem pisano w tym kontekście,

${ }^{23}$ Ibidem, s. 337-338, manifest KW MK na 17. rocznicę rewolucji rosyjskiej, listopad 1934. 
że mimo zakazów „miliony [sic!] robotników socjaldemokratycznych wyjeżdża, by walczyć ramię w ramię ze swymi braćmi klasowymi, proletariatem komunistycznym” na rzecz obrony „hiszpańskiej demokracji”. Walkę o nia i uwolnienie się ,z jarzma faszystowskich reakcjonistów” uznano nie za prywatną sprawę Hiszpanów, lecz za „wspólną sprawę całej rozwiniętej i postępowej ludzkości”. W tym kontekście wzywano robotników: „zmuście wasza klasę rządzącą do [...] stanięcia naprzeciw Niemiec, Włoch i Portugalii”"24. Oprócz więc tworzenia jednolitego frontu pojawiły się zupełnie nowe hasła obrony wartości demokratycznych oraz wymuszenia na rządach wystapienia przeciwko sprzymierzeńcom hiszpańskich rebeliantów, czyli doprowadzenia do wojny na zachodzie Europy.

Ton wobec socjaldemokracji zaostrzył się po raz kolejny w 1937 r. Georgi Dymitrow stwierdził z okazji obchodów 20. rocznicy rewolucji rosyjskiej, że zburzenie kapitalizmu było niemożliwe „bez wyeliminowania socjaldemokracji z ruchu robotniczego". Bez wątpienia oświadczenie sekretarza generalnego Kominternu zatrzymało rozwijające się współdziałanie socjalistów z komunistami w krajach, w których w ogóle do niego doszło. Dymitrow chwalił też Związek Sowiecki z powodu wprowadzenia na świecie jasnego podziału pomiędzy „siłami faszyzmu, kapitalizmu i wojny z jednej strony a siłami pokoju, demokracji i socjalizmu z drugiej”. Gdyby świat rzeczywiście dzielił się na zarysowane powyżej bloki, wybór pomiędzy nimi musiałby nasuwać się samoczynnie. Na to też zapewne Moskwa liczyła. O ochłodzeniu relacji z socjalistami świadczyło też ponowne wypominanie przez Komintern ich współpracy z burżuazja, co przyczyniło się do klęski robotników w trakcie wystapień tuż po I wojnie światowej. Dołączono do tego oskarżenia o działalność rozłamową w szeregach proletariatu, czego od kilku lat już nie robiono ${ }^{25}$.

Z przeanalizowanych oświadczeń i manifestów wynika, iż Moskwa nieprzerwanie dążyła do przechwycenia zwolenników partii socjalistycznych i socjaldemokratycznych, w czym nie różniła się niczym w porównaniu z krokami propagandowymi z lat dwudziestych. W latach 1934-1937 przy okazji obchodów rewolucji w Rosji cały czas namawiano swoich konkurentów w ruchu robotniczym do zawarcia jednolitego frontu działań przeciwko faszyzmowi. Wyciszono nawet najbardziej agresywne sformułowania i oskarżenia. Niemniej jednak o niepowodzenia w tej materii najgłośniej obwiniano właśnie socjaldemokratów, przypisując im współpracę z „wrogami klasowymi” i niechęć do komunizmu, a także nieskuteczność w działaniu. Wszak polityka SPD w Niemczech, nakierowana na nieprowokowanie reżimu Hitlera,

${ }^{24}$ Ibidem, s. 395, 417, 427-428, manifesty KW MK na 19. i 20. rocznicę rewolucji rosyjskiej, listopad 1936 i 1937, artykuł Dymitrowa dla „Communist International” 1938, nr 12.

${ }_{25}$ The Communist International..., s. 412, 414, manifest KW MK na 20. rocznicę rewolucji rosyjskiej, listopad 1937. 
poniosła klęskę. A to przekonało kierownictwa niektórych partii zrzeszonych w Socjalistycznej Międzynarodówce Robotniczej do konieczności podjęcia kroków proponowanych przez Komintern.

Jednakże wydawanie kolejnych manifestów i wygłaszanie przemówień ku czci mijających rocznic to niejedyne kroki propagandowe Moskwy podejmowane przy okazji rocznic rewolucji w Rosji. Niewątpliwym zamiarem rządzących w ZSRS było dotarcie do opinii publicznej w państwach ościennych $\mathrm{w}$ sposób bardziej bezpośredni niż poprzez słowa rzucane w przestrzeń publiczna. Szanse na to stanowiły instrukcje dla kierownictw partii komunistycznych poza ZSRS, aby wysyłali do Moskwy chętnych do wzięcia udziału w rocznicowych uroczystościach ku czci rewolucji rosyjskiej. Nie chodziło przy tym o przysyłanie ludzi należących do kierownictwa partii komunistycznej, czyli przekonanych. W intencjach zapraszających leżała raczej rekrutacja prowadzona w szeregach innych środowisk, podatnych na hasła „jednolitego frontu". Każdy z kandydatów na przyjazd do Związku Sowieckiego miał być sprawdzany pod kątem przydatności. W przypadku Austrii np. najlepiej, aby legitymował się on przynależnościa do Socjalistycznej Partii Austrii, do „reformistycznych” związów zawodowych lub sympatiami wobec Schutzbundu, czyli organizacji, która wywołała powstanie robotnicze w Wiedniu w lutym 1934 r. Promowano również działaczy lokalnych organizacji partyjnych, którzy odebraliby szansę wyjazdu do Moskwy jako ewidentne wyróżnienie. Podsuwano myśl o przysyłaniu również kobiet. Spośród komunistów sugerowano kierować jedynie nowych członków ${ }^{26}$. Z kolei w instrukcji dla Komunistycznej Partii Wielkiej Brytanii (CPGB) uczulano, aby dopilnować tego, że wśród delegatów „nie będzie elementów, które po powrocie nie byłyby użyteczne”. Chciano w Moskwie widzieć aktywnych działaczy robotniczych, „za którymi stoja masy” w „reformistycznych” lub innych zwiazkach zawodowych oraz w organizacjach miejscowych. Także i w instrukcjach do CPGB uczulano, ażeby kandydaci do przyjazdu na obchody rewolucji październikowej zgadzali się z linią „jednolitego frontu”. Partia miała poświęcić zdecydowanie więcej uwagi popularyzowaniu podróży delegatów robotniczych do ZSRS i nagłaśnianiu w prasie tego wydarzenia ${ }^{27}$. Identyczne instrukcje otrzymywał Komitet Centralny Komunistycznej Partii Danii. Przestrzegano go, ażeby przyjrzał się rekrutacji delegatów na listopadowe obchody rewolucji październikowej w Moskwie - zarówno w przypadku Wielkiej Brytanii, jak i Danii zajmowała się tym organizacja Przyjaciele Zwiąku Sowieckiego (Friends of the Soviet Union). Chodziło o wyeliminowanie spośród kandydatów „elementów przypadkowych" i przysłanie użytecznych z punktu widzenia Moskwy².

\footnotetext{
${ }^{26}$ TNA, Government Code \& Cypher School (dalej: HW), 17/1, nr 1307/A, Moskwa do KC Komunistycznej Partii Austrii, 4 X 1934.

${ }_{27}$ Ibidem, 17/19, nr 410-411, Sekretariat KW MK do KC CPGB, Moskwa, 7 X 1935.

${ }^{28}$ Ibidem, 17/10, nr 3935/D, Moskwa do KC Komunistycznej Partii Danii, Moskwa, 7 X 1935.
} 
Zauważyć należy, że Komisja Polityczna Kominternu ${ }^{29}$ musiała przywiazywać dużą wagę do proponowanych kandydatów, skoro sprawdzała ich listy przedstawiane przez sekcje krajowe Międzynarodówki ${ }^{30}$. Zdarzało się, że dyscyplinowała organizatorów wyjazdów z powodu przysłania niewłaściwych osób lub poczynienia niewystarczających przygotowań. Przykładowo w przypadku delegatów z Wielkiej Brytanii na obchody rocznicowe w 1935 r. centrala Kominternu pytała, dlaczego na zaproszenie Moskwy nie odpowiedzieli górnicy, metalowcy i kolejarze. Tłumaczyć musiał się osobiście Harry Pollitt, lider CPGB. W jednym z telegramów ze strony komunistów brytyjskich zaznaczano, że inżynierowie kolejowi odrzucili zaproszenie na obchody rocznicy rewolucji. W kolejnym natomiast tłumaczono, iż górnicy przyjęli zaproszenie do ZSRS, ale „sytuacja w górnictwie nie pozwoliła im przyjechać”. Pollitt miał nadzieję, że w następnym roku ich przybycie na rocznicę rewolucji okaże się możliwe. Zaraz też spotkał się z nakazem, aby w prasie komunistycznej i laburzystowskiej opublikować akceptację zaproszenia do Moskwy i wysłać delegatów górniczych na obchody 1 Maja $^{31}$. Jak widać, czyjaś obecność lub nieobecność była traktowana prestiżowo przez władze III Międzynarodówki, które rozliczały podległe jej sekcje krajowe z zadania przysyłania na kolejne rocznice odpowiednich aktywistów robotniczych.

Inny element „świętowania” rocznic przewrotu bolszewickiego stanowiło propagowanie przez sekcje krajowe Kominternu odpowiednich haseł na terenie własnych krajów. Dla przykładu rumuńscy komuniści otrzymali z Moskwy zadanie organizowania 7 XI 1935 r. manifestacji u siebie i głoszenia na nich konkretnych treści w celu nadania im antyfaszystowskiego charakteru:

1) utworzenie jednolitego frontu proletariatu, skierowanego przeciw wojnie w Abisynii i przeciw „faszyzmowi niemieckiemu” - do kampanii mieli być wciagnięci „robotnicy socjaldemokratyczni i reformistyczni”;

2) sprzeciwianie się eksportowi ropy i zboża do Włoch (co musiało uderzać w podstawy gospodarki rumuńskiej);

3) bronienie pokoju i Związu Sowieckiego przed agresja;

4) przeciwstawianie się sojuszowi z Polską i popieranie układu o wzajemnej pomocy z ZSRS (co przeorientowałoby całkowicie politykę zagraniczna Bukaresztu);

${ }^{29}$ Komisja Polityczna to pozastatutowy organ Kominternu. Zajmowała się w pierwszej połowie lat trzydziestych mianowaniem i nadzorowaniem ludzi do odpowiednich zadań. Obejmowała sekretariaty regionalne, sekretarzy redakcji periodyków podległych Międzynarodówce, instruktorów itp. Po VII Zjeździe utraciła swe znaczenie.

${ }^{30}$ TNA, HW, 17/1, nr 0844/A, Komisja Polityczna do KC Komunistycznej Partii Austrii, 15 X 1934.

${ }^{31}$ Ibidem, nr 1398/A, Komisja Polityczna do KC Komunistycznej Partii Austrii, 29 XI 1934; ibidem, 17/19, nr 489 i 510 z Moskwy oraz 13-14, 17 z Londynu, wymiana korespondencji między centralą Kominternu a Komunistyczną Partią Wielkiej Brytanii, 23 XI 5 XII 1935. 
5) żądania obrony interesów „mas robotniczych i chłopskich”;

6) postulaty likwidacji długów i pomocy dla głodujących;

7) dążenia do powiększenia zakresu praw demokratycznych w Rumunii (która była przecież państwem o ustroju autorytarnym w tym czasie);

8) konieczność zniesienia „wojującej” cenzury i „konserwatywnych zmian w konstytucji”.

Odradzano natomiast podnoszenie haseł „precz z rządem” i „za państwem chłopskim”, gdyż takie leżały w arsenale Narodowej Partii Chłopskiej, której członków nazywano popularnie caranistami ${ }^{32}$. Tak szczegółowy instruktarz świadczył o dbałości władz sowieckich przykładanej do propagandowego wykorzystania kolejnych rocznic rewolucji.

$\mathrm{Na}$ zakończenie zauważyć wypada jeszcze jeden aspekt rocznicowych obchodów rewolucji rosyjskiej. Otóż każdorazowo centralnym punktem była wielka parada na Placu Czerwonym, którą odbierały najważniejsze osobistości w państwie ze Stalinem na czele. Dostanie się na trybunę honorowa $\mathrm{w}$ pobliżu jego osoby traktowano z oczywistych względów jako ogromny zaszczyt. Każdorazowo defiladzie towarzyszył również komponent wojskowy. Przed „wielkim wodzem postępowej ludzkości” przechodziły kolejno oddziały wszystkich rodzajów sił zbrojnych. Z powodu braku dostępu do archiwaliów postsowieckich można się jedynie domyślić, że ich dobór nie był przypadkowy i służył propagowaniu potęgi Związku Sowieckiego. Docenić mogli to wprawnym okiem attaché wojskowi krajów ościennych, piszący następnie raporty dla swoich ministerstw. Szczególnie w kraju o tak utrudnionym dostępie do informacji w kwestiach wojskowych obserwacja listopadowej parady pozwalała dowiedzieć się, jakimi środkami militarnymi dysponowała Moskwa.

Wojskowi zwracali uwagę na różnorakie kwestie na paradach. Przykładowo przedstawiciele Wielkiej Brytanii byli wyczuleni na słabą dyscyplinę i mizerny wygląd żołnierzy bioracych udział w przemarszu wojsk. Przyznać jednak trzeba, że notowali w tym względzie postępująca poprawę. Mieli zwyczaj porównywać każdorazowo, jakie rodzaje wojsk uczestniczyły w kolejnych latach, ile i jaki sprzęt prezentowano. Dla przykładu w trakcie parady w 1933 r. pojawiło się 250 czołgów różnego typu, czyli typowo ofensywnej broni. W 1935 r. zwiększony był udział broni przeciwlotniczej - 60 dział zamiast $42 \mathrm{w}$ poprzednim roku. W trakcie tego samego przemarszu uwagę zwróciła mniejsza liczba czołgów ciężkich. Jednakże wśród nich raport wyszczególniał 8 superciężkich pojazdów powyżej 40 ton z 3 działami i 4 karabinami maszynowymi. Z kolei rok później nowością był oddział motocyklistów, złożony z 96 osób. Pierwszy raz zaprezentowano średnią i ciężką artylerię. Natomiast w $1934 \mathrm{r}$. Kreml pochwalił się również posiadaniem ofensywnej broni gazowej, której zakazu domagał się głośno w trakcie rokowań rozbrojeniowych. Rozmaicie wypadał udział lotnictwa w pokazach. Nieraz w ogóle nie mogło się ono

${ }^{32}$ Ibidem, 17/6, nr 4292/TS, Moskwa do Pragi, 10 X 1935. 
zaprezentować z powodu zachmurzenia, np. w 1935 r. Ale już w następnym roku uczestniczył w defiladzie nowy samolot rekonesansowy, przy mniejszym w porównaniu z paradą pierwszomajową udziale bombowców i lekkich jednoosobowych myśliwców. W raporcie brytyjskiego attaché wojskowego płk. Erica Skaife’a z 1935 r. znalazł się załącznik, w którym wyspecyfikowano 61 typów zaprezentowanej na paradzie broni. Zawsze uwagę obserwatorów zagranicznych przykuwały tzw. incydenty, czyli różnego rodzaju nieprzewidziane awarie sprzętowe. I tak np. w 1933 r. zepsuł się jeden z traktorów ciagnących armatę, blokując cały przemarsz na dłuższą chwilę - ciężki pojazd trzeba było odholować za pomocą specjalistycznego sprzętu. O wiele groźniej wyglądał wypadek jednego z przelatujacych nad Placem Czerwonym bombowców w 1936 r. W trakcie przelotu na widzów spadły części jednego z silników maszyny, który rozpadł się nieoczekiwanie dokładnie na wysokości trybuny honorowej - odnotowano ofiary śmiertelne wśród cywilnych obserwatorów pokazu. Nic dziwnego, że zewnętrzni obserwatorzy, choć zauważali postęp technologiczny w armii sowieckiej, to jednak nie mieli dobrej opinii o jakości posiadanego przez nią sprzętu ${ }^{33}$.

Podsumowując, zaznaczyć wypada, że coroczne obchody rocznic przejęcia władzy w Rosji przez bolszewików posiadały ogromne znaczenie dla prowadzonej przez władze moskiewskie propagandy. Obok pochodów pierwszomajowych listopadowe święta miały niewątpliwie najbardziej uroczysty charakter. W ramach przygotowań ustalano listę haseł, których było kilkadziesiąt i które następnie głosiła uczestniczacca w obchodach ludność. Ich treść zmieniała się z roku na rok, ale w latach trzydziestych powtarzały się hasła pokojowe, wychwalające zdobycze socjalizmu i „wielkiego Stalina”, antyfaszystowskie (oprócz niechęci do Niemiec hitlerowskich czy ich interwencji w Hiszpanii, prezentowano żądania uwolnienia więźniów politycznych, głównie Ernsta Thälmanna - przywódcy KPD), antykapitalistyczne, antyburżuazyjne i skierowane przeciwko socjaldemokratom. Oprócz „spontanicznych” wystapień ludności najważniejszy tekst programowy przygotowywał co roku Komitet Wykonawczy Międzynarodówki Komunistycznej. Kilkustronicowe manifesty skupiały się treściowo na czterech kwestiach. Oprócz wychwalania Stalina, z czym wiązała się jego rozprawa z elitami tzw. starych bolszewików w latach 1936-1938, poruszania kwestii międzynarodowych, a wśród nich głównie atakowania „faszyzmu niemieckiego” i „militarystycznego japońskiego imperializmu”, „demaskowania rozbijackiej roboty” liderów socjaldemokracji, podnoszono jeszcze wagę rewolucji październikowej dla całego świata,

33 TNA, FO, 371/17252, N8410/113/38, Chilston do Simona, Moskwa, 16 XI 1933 z załączonym raportem Leslie Potta (p.o. konsula generalnego Wielkiej Brytanii w ZSRS) z 14 XI; ibidem, 371/18313, N6528/120/38, Noel Charles (radca ambasady brytyjskiej w Moskwie) do Simona, Moskwa, 19 XI 1934 z załączonym raportem Skaife z 17 XI; ibidem, 371/19458, N6033/54/38, Skaife do Chilstona, Moskwa, 15 XI 1935; ibidem, 371/20351, N5720/565/38, Chilston do Anthony'ego Edena (od grudnia 1935 r. szef brytyjskiej dyplomacji), 16 XI 1936. 
a szczególnie dla „narodów Związku Sowieckiego” oraz wieloletnie dokonania „dyktatury proletariatu” w różnych dziedzinach. Coroczne obchody miały więc na celu niewątpliwie kształtowanie mitu założycielskiego państwa oraz prezentowanie celów politycznych władz. Manifesty KW MK cechowały się bardzo emocjonalnym językiem, chcąc wywołać jak najsilniejsze emocje u słuchaczy - sympatię dla ZSRS oraz gniew i niechęć wobec jego przeciwników. Nie było w prezentowanych treściach niczego szczególnie merytorycznego, co oznaczało, że dokumenty przygotowywano przede wszystkim pod katem dotarcia do odbiorców niezbyt wyrobionych intelektualnie. Jednocześnie nielicznie pojawiały się w nich czołobitne zachwyty nad Stalinem, co mogło wskazywać, że manifesty kierowano raczej do robotników spoza ZSRS, którzy żyjąc w innej kulturze politycznej niż Rosjanie, nie zrozumieliby wiernopoddańczych sformułowań. Starano się w nich raczej zaszczepić uczucie buntu wobec władz politycznych. Natomiast tych, którzy przyjeżdżali do Moskwy, aby uczestniczyć w obchodach, starano się na tyle zachwycić potęga państwa i entuzjazmem miejscowej ludności wobec władz, żeby po powrocie do domów stali się gorliwymi ,apostołami” rewolucji w stylu rosyjskim.

Podobne w treściach enuncjacje zgłaszali inni przedstawiciele władz sowieckich, którzy przy okazji rocznicy rewolucji zabierali głos. Bez względu na to, czy był to Mołotow, Litwinow, Dymitrow, czy jeszcze inni politycy ze szczytów władzy, treści koncentrowały się wokół sposobu sprawowania „dyktatury proletariatu w ZSRS", spraw międzynarodowych i relacji z innymi nurtami w ramach ruchu robotniczego. Wystapienia wyglądały na przemyślana „politykę informacyjną" Moskwy. Ton ich wypowiedzi był już zdecydowanie mniej nasycony przymiotnikami w celu wywołania emocji odbiorców i bardziej konkretny i merytoryczny. Widać, że swe wypowiedzi kierowali już do kogoś innego niż świat robotników, mało wyrobionych politycznie, aczkolwiek zaangażowanych. W latach 1933-1939 nie zdarzyło się, aby głos z okazji obchodów rocznicy rewolucji zabrał sam Stalin - najwidoczniej uznał, że nie było to potrzebne.

Proporcja podnoszonych tematów z poszczególnych dziedzin zależała najwyraźniej od wydarzeń danego roku. I tak np. w 1934 r. wszystkie właściwe poruszane sprawy dotyczyły budowania „jednolitego frontu” przeciwko faszyzmowi i wojnie, pomijając tematykę polityki międzynarodowej. Z kolei w 1938 r., czyli niedługo po konferencji monachijskiej, w wypowiedziach dominowały sprawy zagraniczne, a „jedność działania” ruchu robotniczego została całkowicie pominięta. Podobnie było rok później. Szczególną rolę spełniały w celebracjach defilady wojskowe. O ile miejscowa ludność mogła zachwycać się liczbą różnorakich oddziałów, o tyle obserwatorzy zagraniczni większą uwagę skupiali na jakości prezentowanego uzbrojenia. Pokazanie takich, a nie innych rodzajów broni miało niewątpliwie charakter perswazji. Chodziło o wysłanie ostrzeżenia lub o namówienie do współpracy potencjalnych sojuszników lub mniejszych sąsiadów, którzy liczyć się musieli z użyciem śmiercionośnych broni przeciw nim w razie odmowy współdziałania. 


\section{Streszczenie}

Związek Sowiecki jako typowy kraj totalitarny miał ogromne tendencje do celebrowania rozmaitych wydarzeń, ażeby przy tej okazji prezentować ważne dla siebie treści. Jedna z nich były kolejne rocznice rewolucji rosyjskiej. W artykule scharakteryzowano podstawowe sposoby wpływania Moskwy na opinię publiczną w latach 1933-1939. Istotne było przyjrzenie się, czy z powodu kolejnych rocznicowych obchodów rewolucji październikowej dało się zauważyć treści, które podkreślały wzmacnianie dyktatury Józefa Stalina w ZSRS, zmianę kursu polityki zagranicznej kraju czy propagowanie polityki Międzynarodówki Komunistycznej. Czy oprócz wskazanych tematów poruszano podczas okolicznościowych przemówień i manifestów jakieś inne wątki? Jakie proporcje zajmowały zagadnienia wewnętrzne i zewnętrzne w wygłaszanych przy tej okazji enuncjacjach? Do kogo były one w głównej mierze adresowane i w jaki sposób to czyniono? Do czego w ogóle wykorzystywano obchody udanego przewrotu bolszewickiego z 1917 r.? Czy oprócz publikowania kolejnych dokumentów „ku czci” starano się sięgnąć po inne narzędzia wpływania na opinię publiczną? Na powyższe pytania badawcze można było odpowiedzieć, analizując wypowiedzi najważniejszych polityków w Związku Sowieckim lub wyznaczonych przez nich do tego osób. Zasadne okazało się również przeanalizowanie innych niż słowa elementów oddziaływania propagandowego na opinię publiczną.

\section{Anniversaries of the "Russian Revolution" in Soviet propaganda in 1933-1939}

The Soviet Union as a typical totalitarian regime was strongly inclined to celebrate various events which were of great propaganda value to the regime. One of such occasions was the anniversary of the Russian Revolution. The article presents basic ways of influencing the public opinion in Soviet Russia in 1933-1939. Special attention is paid to the fact whether successive celebrations of the "October Revolution" made more evident contents that emphasised the strengthening of Stalin's dictatorship in the USSR, a change in the course of Soviet foreign policy, or propagated the policy of the Communist International. Whether there were some other subjects and topics brought up in occasional speeches and manifestos? What was the proportion between internal and external affairs brought up in enunciations delivered on this occasion? To whom were they addressed and in what way? And what was the actual purpose of the anniversary celebrations of the victorious Bolshevik coup of 1917 ? Were there, apart from successive publications of documents "in honour", any other tools of influencing the public opinion? All these questions can be answered after a thorough analysis of speeches and statements made by the leading politicians of the Soviet Union or specially appointed people. It is also highly reasonable to analyse other - than words - elements of propaganda tactics to influence people.

\section{Bibliografia}

Borsányi G., The Life of the Communist Revolutionary, Béla Kun, New York 1993.

Bullock A., Hitler i Stalin. Żywoty równoległe, t. I, Warszawa 1993.

Firsow F.I., Stalin i Komintiern, „Woprosy Istorii” 1989, № 9, s. 3-19.

Fomitschow W., Organisation und Entwicklung der Aktenführung im Apparat der Komintern. Zusammensetzung und Inhalt der Bestände von Personalakten (am Beispiel des Beständes für Deutschalnd), w: Biographisches Handbuch zur Geschichte der Kommunistischen Internationale, Hrsg. M. Buckmiller, K. Meschkat, Berlin 2007, s. 55-73.

Furet F., Przeszłość pewnego złudzenia. Esej o idei komunistycznej w XX w., tłum. J. Górnicka-Kalinowska, M. Ochab, Warszawa 1996. 
Huber P., Das Führungskorps der Komintern. Ein soziobiographischer Querschnitt, w: Biographisches Handbuch zur Geschichte der Kommunistischen Internationale, Hrsg. M. Buckmiller, K. Meschkat, Berlin 2007, s. 195-246.

Huber P., The Moscow Headquarter of the Comintern: Departments, Leading Organs, Soviet Influence and Decision Making, w: Mechanism of Power in the Soviet Union, ed. N.E. Rosenfeldt, B. Jensen, E. Kulavig, London 2000, s. 71-100.

Huber P., Structure of the Moscow Apparatus of the Comintern and Decision-Making, $\mathrm{w}$ : International Communism and the Communist International, ed. T. Rees, A. Thorpe, Manchester 1998, s. 41-64.

Jeziorny D., Pakt Ribbentrop-Mołotow - przełom czy kontynuacja w europejskiej polityce Zwiazku Sowieckiego, „Polski Przegląd Stosunków Międzynarodowych” R. II, 2012, s. $151-183$.

Jeziorny D., Stosunki pomiędzy Moskwa a Komunistyczna Partia Wielkiej Brytanii (19341936) $w$ świetle dokumentów brytyjskiego wywiadu radiowego, w: $Z$ dziejów Rosji i Polski w XX wieku. Księga dedykowana profesorowi Richardowi Pipesowi, red. H. Kocój, R. Małek, M. Szczerbiński, Gorzów Wlkp. 2006, s. 89-109.

Kalicka F., Problemy jednolitego frontu $w$ międzynarodowym ruchu robotniczym (1933-1935), Warszawa 1962.

Kołakowski L., Główne nurty marksizmu, cz. 2: Rozwój, Warszawa 1989.

Kulikowa G.B., Iz istorii formirowanija kulta licznosti Stalina (A. Barbius i sozdanije biografii „otca narodow” w naczale 1930-ych gg.), „Otieczestwiennaja Istorija” 2006, № 1, s. 98-107.

Materski W., ZSRR wobec kwestii bezpieczeństwa zbiorowego w okresie międzywojennym (Liga Narodów, rozbrojenie, systemy regionalne), „Studia z Dziejów ZSRR i Europy Środkowej” 1980, t. XVI, s. 124-131.

McDermott K., Stalin and the Comintern during the „Third Period”, 1928-1933, „European History Review" 1995, vol. XXV, no. 3, s. 409-429.

McDermott K., Agnew J., The Comintern. A History of International Communism from Lenin to Stalin, Basingstoke 1996.

McMeekin S.A., Münzenberg. Rise and Fall of a Communist Tycoon, 1917-1940, Ph.D. University of California, Berkeley 2001, http://proquest.umi.com (dostęp: 3 IV 2009).

Mieltiuchow M., Sowietsko-polskije wojny, izd. 2, Moskwa 2004.

Morgan K., Harry Pollitt, Manchester 1993.

Steiner Z., The Soviet Commissariat of Foreign Affairs and the Czechoslovakian Crisis in 1938: New Material from Soviet Archives, „The Historical Journal” 1999, vol. XLII, no. 3 , s. $751-779$.

Bi og r a m: Dariusz Jeziorny - dr hab., prof. UŁ; Katedra Historii Powszechnej Najnowszej Uniwersytetu Łódzkiego, specjalizujący się w historii dyplomacji okresu międzywojennego, głównie brytyjskiej polityki zagranicznej oraz myśli politycznej. Najważniejsze publikacje: Dyplomacja brytyjska wobec koncepcji paktu wschodniego (1933-1935). Analizy, projekty, działania, Łódź 2011; Londyn a spuścizna po monarchii Habsburgów. Sprawa Austrii w koncepcjach i praktyce dyplomatycznej Wielkiej Brytanii (1918-1919), Toruń 2002. E-mail: dariuszjeziorny@uni.lodz.pl. 